\title{
Crônica 1
}

\section{Papa Francisco envia mensagem ao Brasil para a Campanha da Fraternidade Ecumênica 2021 \\ Conferência Nacional dos Bispos do Brasil}

O papa Francisco enviou uma mensagem aos brasileiros por ocasião do início da quaresma e da abertura da Campanha da Fraternidade (CFE) 2021, na quarta-feira de Cinzas, 17 de fevereiro, às 10 horas. Em 2021, o tema proposto é Fraternidade e diálogo: compromisso de amor e o lema Cristo é a nossa Paz: do que era dividido fez uma unidade (Ef 2,14). A mensagem do santo padre aos brasileiros foi apresentada na solenidade de abertura virtual de abertura da CFE, lida na voz do jornalista do Vatican News, Silvonei Protz.

No texto, o santo padre afirma que a quaresma convida a todos para um tempo de intensa reflexão e revisão de vida. "O senhor Jesus, que nos convida a caminhar com ele pelo deserto rumo à vitória pascal sobre o pecado e a morte, faz-se peregrino conosco também nestes tempos de pandemia", escreveu o papa.

$\mathrm{Na}$ mensagem, o papa lembra que é tradição há várias décadas a promoção da Campanha da Fraternidade pela Igreja no Brasil. Ele define a campanha como "um auxílio concreto para a vivência deste tempo de preparação para a Páscoa". No documento, o papa afirma que, neste ano de 2021, com o tema Fraternidade e diálogo: compromisso de amor, os fiéis são convidados a "sentar-se a escutar o outro" e, assim, superar os obstáculos de um mundo que é muitas vezes "um mundo surdo".

Confira a íntegra do documento aqui, com a assinatura digital do santo padre.

Disponível em: <https://www.cnbb.org.br/papa-francisco-envia-mensagem-ao-brasil-para-acampanha-da-fraternidade-ecumenica-2021/>. 


\section{Crônica 2}

\section{Dom Rodolfo Weber fala sobre encontro do papa com a Federação Luterana Mundial \\ Conferência Nacional dos Bispos do Brasil}

O papa Francisco recebeu em audiência em 25 de junho, no Vaticano, uma delegação da Federação Luterana Mundial. Na ocasião, o pontífice recordou sua visita a Lund, cidade onde a federação foi fundada, no âmbito de sua viagem apostólica à Suécia, em 2016.

Diante dessa visita, o portal da Conferência Nacional dos Bispos do Brasil (CNBB) conversou com o arcebispo de Passo Fundo (RS) e referencial do diálogo católico-luterano no Brasil, dom Rodolfo Luís Weber, que falou sobre como anda o caminho desse diálogo aqui no país.

Ao contextualizar a visita da federação ao papa, dom Rodolfo disse que a Igreja nos seus ensinamentos sobre a convivência com pessoas de outros credos, no Concílio Vaticano II, disse claramente que temos liberdade religiosa, isto é, o direito de crer ou não crer, o direito de escolher uma pertença a uma Igreja, a uma religião, mas uma escolha livre, consciente e responsável. "Por isso a Igreja defende esse princípio como um direito fundamental do ser humano na sua capacidade de escolha, sua liberdade de escolher a fé que vai professar e a pertença a qual religião vai fazer", salientou.

Dentro desse contexto, dom Rodolfo afirmou que a Igreja também ensina que é da nossa natureza, da essência do ser cristão ser ecumênico, isto é, dialogar com as pessoas, com os cristãos que tem a mesma origem em Cristo, o mesmo batismo, um só Deus. "Portanto, nós temos um elemento em comum de diálogo: exatamente a partilha, a partir da fé no mesmo Deus e do mesmo batismo. Portanto, um ensinamento e uma obrigação de toda a Igreja”, disse.

E segundo dom Rodolfo o exemplo parte a partir do papa Francisco que regularmente promove o encontro com pessoas de outras igrejas, como aconteceu agora com a Federação Luterana Mundial. "Com a Federação Luterana Mundial a Igreja tem um diálogo bem próximo e já vai de longa data, por isso constantemente nós nos encontramos para podermos dialogar especialmente com a federação luterana”, salientou.

\section{O que se está realizando no Brasil?}

$\mathrm{O}$ arcebispo de Passo Fundo explicou que a CNBB tem a representação de alguns bispos que representam a Igreja católica, assim como os luteranos da Igreja Evangélica de Confissão Luterana no Brasil (IECLB) também tem seus representantes. "Nós realizamos vários momentos. Em 2017, por exemplo, preparamos a celebração dos 500 anos da Reforma. Foi feita 


\section{Revista Brasileira de Diálogo Ecumênico e Inter-religioso}

uma celebração na Catedral de Porto Alegre, onde a parte católica com a representação da presidência da CNBB e também a parte luterana se encontrou para rezar".

Dom Rodolfo conta que, regularmente, eles se encontram ao menos duas vezes em reuniões anuais. "Certamente para estabelecer e aprofundar o nosso diálogo. Nesse ano não fizemos a reunião presencial, mas fizemos a reunião virtual”, disse.

De acordo com ele, nesse ano os membros se concentraram principalmente em fazer memória de como aconteceu e está acontecendo esse diálogo nos últimos anos. "Tivemos ajuda de pessoas que viveram os primórdios desse diálogo e que nos relataram os passos, os avanços, os pontos divergentes, mas acima de tudo foi manifesto o profundo desejo de dialogar, de compreender-se mutuamente, de respeitar-se ainda mais. Portanto, com os luteranos nós temos um diálogo sistemático e constante e um desejo de aprofundamento", contou.

Ainda segundo dom Rodolfo, foi conversado nessa última reunião sobre a Campanha da Fraternidade Ecumênica, que foi abraçada com muita profundidade com a IECLB. "Com eles também reavaliamos e sentimos com pesar que o tema era o diálogo e, por outro lado, as vezes foi compreendido como um conflito, por isso nós queremos acima de tudo com os irmãos da Igreja Luterana estabelecer esses laços de diálogo, de conversa, de partilha, sabendo muito claramente o que nos distingue e o que nos une, mas as distinções não são motivos de agressividade e rejeição, mas são desafios para sermos mais fraternos e dialogarmos com mais profundidade", finalizou.

Disponível em: <https://www.cnbb.org.br/dom-rodolfo-weber-fala-sobre-encontro-do-papacom-a-federacao-luterana-mundial/> . 


\section{Crônica 3}

\section{CMI será agraciado com o prêmio Bridge Builder Award 2021}

Conselho Nacional de Igrejas Cristãs do Brasil

O Conselho Mundial de Igrejas (CMI) receberá, em agosto, o prêmio Bridge Builder Award 2021. O reconhecimento é pelo trabalho que o conselho faz em construir pontes de entendimento entre povos, nações e comunidades, tanto em escala nacional, quanto global.

A entrega será feita na Noruega, diretamente das mãos do primeiro ministro daquele país. Na cerimônia, também participarão representantes da comunidade judaica e islâmica.

Confira a íntegra da notícia, em espanhol, aqui.

Disponível em: <https://www.conic.org.br/portal/noticias/3859-cmi-sera-agraciado-com-opremio-bridge-builder-award-2021>. 


\section{Crônica 4}

\section{CEBI elege nova Direção Nacional, Conselho Nacional e Conselho Fiscal}

Conselho Nacional de Igrejas Cristãs do Brasil

Foram seis dias de celebrações, reflexões, estudos e escolha da nova coordenação colegiada que durante os dias 29 e 30 de maio e 3 a 6 de junho marcaram a XXII Assembleia Nacional do CEBI, onde se celebrou a vida e o compromisso com a justiça dos pobres.

Com uma média de 50 participantes por dia, a assembleia Nacional do Centro de Estudos Bíblicos (CEBI) reuniu delegadas e delegados eleitas(os) pelos estados e associadas(os). Estiveram também presentes instituições parceiras e agências internacionais apoiadoras dos projetos do CEBI em todo o Brasil: CESE, CONIC, REBILAC, AdveniatAlemanha, DKA-Áustria, Igreja da Suécia, PJ Nacional, Juventude Evangélica da IECLB, Evangelicxs Pela Diversidade, Rede de Mulheres Negras de Pernambuco e GT Juventudes da IEAB, além de contar com as presenças da reverenda Lilian Conceição da Silva e o pastor Marcos Monteiro.

Em clima de cooperação e sororidade, elegeu-se a Direção Nacional do CEBI, o Conselho Nacional e o Conselho Fiscal para o triênio 2021-2024. A nova direção, dentre outras competências, terá a missão de acompanhar e administrar todos os setores do CEBI Nacional.

As três pessoas da direção, juntamente com as representantes de cada região do Brasil, formam o novo Conselho Nacional do CEBI.

\section{Conselho Nacional \\ Direção Nacional \\ Rafael Rodrigues da Silva \\ Maria de Fátima Castelan \\ Paulo Ueti}

Representantes de cada região do Brasil

Rui Barauna (Região Amazônica)

Wellington Oliveira (Região Norte)

Silvia Souza (Região Nordeste)

Muria Carrijo (Região Centro-Oeste)

Erivaldo José da Silva (Região Sudeste)

João Osmar (Região Sul) 
Crônicas

Conselho Fiscal

Adriana Amorim Fernandes

José Nascimento

Fabiano Romes Maciel

Disponível em: <https://conic.org.br/portal/noticias/3855-cebi-elege-nova-direcao-nacionalconselho-nacional-e-conselho-fiscal>. 